Published in final edited form as:

Neurol Clin. 2013 May ; 31(2): 597-619. doi:10.1016/j.ncl.2013.01.009.

\title{
Inherited Peripheral Neuropathies
}

\author{
Mario A. Saporta, MD, $\mathrm{PhD}^{1}$ and Michael E. Shy, $\mathbf{M D}^{2}$ \\ ${ }^{1}$ Biological Sciences Institute, Universidade Federal do Rio de Janeiro, Brazil \\ ${ }^{2}$ Department of Neurology, University of lowa, lowa City, IA, USA
}

\section{SYNOPSIS}

Charcot Marie Tooth disease (CMT) is a heterogeneous group of inherited peripheral neuropathies in which the neuropathy is the sole or primary component of the disorder, as opposed to diseases in which the neuropathy is part of a more generalized neurological or multisystem syndrome. Due to the great genetic heterogeneity of this condition, it can be challenging for the general neurologist to diagnose patients with specific types of CMT. Here, we review the biology of the inherited peripheral neuropathies, delineate major phenotypic features of the CMT subtypes and suggest strategies for focusing genetic testing.

\section{Keywords}

Charcot Marie Tooth; Inherited Neuropathy; Genetic Testing

\section{INTRODUCTION}

First described at the end of the $19^{\text {th }}$ century by French neurologists Jean Martin Charcot and Pierre Marie and British neurologist Howard Henry Tooth, Charcot Marie Tooth disease (CMT) is now identified as the most common inherited neurological condition, affecting approximately 1 in 2500 people ${ }^{1}$. CMT is frequently the final diagnosis of patients with previously unidentified (idiopathic or cryptogenic) peripheral neuropathies ${ }^{2}$, underscoring the need for better awareness and strategies to help general neurologists navigate through the clinical and molecular diagnosis of this fascinating group of neuropathies. Recent advances in molecular biology have demonstrated that CMT is genetically heterogeneous, with at least 50 genes known to cause CMT when mutated. The majority of patients have an autosomal dominant form of CMT, though X-linked and autosomal recessive inheritances are not uncommon. Here, we describe the characteristics of various forms of CMT, their biological substrate, as well as the current strategy for genetic testing.

\section{THE BIOLOGY OF INHERITED PERIPHERAL NEUROPATHIES}

A common feature of the majority of genes mutated in CMT is the role they play in maintaining the structure or function of the two main cellular components of the peripheral nervous system, Schwann cells and the axons of peripheral neurons (ventral horn spinal motor neurons and dorsal root ganglia sensory neurons) (Figure 1).

\footnotetext{
(C) 2013 Elsevier Inc. All rights reserved.

Correspondence: Mario A. Saporta, Rua Republica do Peru 362/602, Rio de Janeiro 22021-040 Brazil, mariosaporta@gmail.com.

Publisher's Disclaimer: This is a PDF file of an unedited manuscript that has been accepted for publication. As a service to our customers we are providing this early version of the manuscript. The manuscript will undergo copyediting, typesetting, and review of the resulting proof before it is published in its final citable form. Please note that during the production process errors may be discovered which could affect the content, and all legal disclaimers that apply to the journal pertain.
} 
The first genes identified to cause CMT express proteins that are essential for compact $(P M P 22, M P Z)$ and non-compact (GJBI) myelin structure ${ }^{3}$ and their altered expression cause demyelination or dysmyelination. A novel concept derived from the identification of PMP22 duplication as the basic pathomechanism in CMT1A is that of gene/protein dosage. It became clear that the correct stoichiometry of PMP22 is necessary to maintain compact myelin integrity. Too much PMP22 (duplication) causes CMT1A; too little (haploinsufficiency) causes Hereditary Neuropathy with Liability to Pressure Palsies (HNPP) (see below) ${ }^{4}$. Abnormal expression of MPZ also causes demyelination, although in this case usually due to point mutations in the $M P Z$ gene.

An important biological feature common to both neurons and Schwann cells are their highly specialized and polarized cellular architecture ${ }^{5}$. While the polarization of neurons is a wellrecognized feature of these cells, with their axons extending more than 1 meter in humans, Schwann cells are also very polarized, as their membranes have to expand while they concentrically wrap around axons. To overcome the long distances between the cell nucleus and the more distal segments of the membrane, Schwann cells have areas of non-compact myelin rich in gap junctions that provide a radial pathway directly across the layers of the myelin sheath. Connexin 32 (Cx32), the protein expressed by the GJB1 gene, is the main component of gap junctions in the myelin of Schwann cells and this may explain at least in part why GJB1 mutations cause CMT1X ${ }^{6}$. The high polarization of neurons and Schwann cells may also explain why mutations in ubiquitously expressed genes such as MFN2, $G D A P 1$ or $G A R S$, cause preferential dysfunction of the peripheral nervous system. The length-dependent neuropathy commonly found in patients with CMT seems to support the hypothesis that distal peripheral axons are especially susceptible to disruptions in organelle and metabolite axonal transport.

Schwann cells and axons interact at multiple points along the peripheral nerve, including the adaxonal membrane, paranodal myelin loops, microvilli and justaparanodal basal lamina. These interactions are mutually beneficial, providing trophic support to the axon and myelinating cues to the Schwann cell. An example of this important interaction is the occurrence of secondary axonal degeneration in all forms of demyelinating CMT. This axonal degeneration is deemed to occur as a consequence of ineffective Schwann cell support to the axon and is actually more directly related to clinical functional impairment than the demyelination itself ${ }^{7}$.

Lastly, several recent studies have demonstrated a specific susceptibility of Schwann cells to mutations yielding misfolded proteins, as seen in certain $P M P 22^{8}$ and $M P Z^{9,10}$ point mutations. Misfolded proteins accumulate in the endoplasmic reticulum of Schwann cells inducing a transitory Unfolded Protein Response (UPR), a series of cellular events that help the ER to cope with the increased metabolic demand caused by misfolded protein retention. This, in turn, causes downregulation of the myelination program genes and dedifferentiation of Schwann cells, a toxic gain of function that worsens the demyelination and is potentially amenable to therapeutical intervention ${ }^{11,12}$.

\section{CLINICAL AND NEUROPHYSIOLOGICAL FEATURES}

CMT is clinically as well as genetically heterogeneous, with variability in the age of onset, speed of progression and electrodiagnostic findings. Though both motor and sensory nerves are usually affected, the more prominent phenotypic characteristic is related to motor difficulty in most cases. The "classic" phenotype includes steppage gait, pes cavus, sensory loss in a stocking/glove distribution, inverted champagne bottle legs, and atrophy in the hands ${ }^{13-15}$. Physical exam also shows decreased or absent deep tendon reflexes, often diffusely but virtually always involving the Achilles tendon. Findings are usually 
symmetric ${ }^{16}$. Onset is typically in the first to second decade in classic cases, though this may differ depending on the genetic subtype, including early-onset, infantile forms (historically designated Dejerine-Sottas syndrome) and late-onset, adult forms. Symptoms are usually slowly progressive, especially for the classic and late-onset phenotypes, but can be rather severe in early-onset forms. Patients usually have impaired proprioception with balance difficulty. Neuropathic pain affects around $20 \%$ of CMT patients.

Nerve conductions allow for classification into demyelinating, axonal, or intermediate groups, based on the motor nerve conduction velocities (MNCV) and compound muscle action potential amplitudes (CMAP). The standard cut off for demyelinating MNCV in the upper extremities is $38 \mathrm{~m} / \mathrm{s}$. Velocities between 35 and $45 \mathrm{~m} / \mathrm{s}$ may be considered intermediately slowed, and greater than $45 \mathrm{~m} / \mathrm{s}$ are considered axonal if there is a decrease in CMAP. Conduction velocities are performed in the arms because CMAP amplitudes are often unobtainable in the legs even for demyelinating forms of CMT due to impaired interactions between abnormal myelin and the underlying axon. CMT can be divided into subtypes based on electrodiagnostic features and inheritance pattern. Those with autosomal dominant inheritance and a demyelinating phenotype are said to have CMT type 1 (CMT1). Those with autosomal dominant inheritance and an axonal phenotype have CMT type 2 (CMT2), and those with autosomal recessive inheritance, regardless of the electrodiagnostic features, have CMT type 4 (CMT4). Those with CMT inherited in an X-linked fashion has CMT type X (CMTX). The subtypes are then further divided genetically based on the gene mutated. The gene or the type of mutation in the gene that causes the condition, defines each genetic subtype, as shown on Table 1. The usual electrodiagnostic finding in demyelinating inherited neuropathies is widespread, uniform slowing of conduction velocities, as opposed to the multifocal, segmental slowing found in demyelinating acquired neuropathies, where temporal dispersion and conduction block is frequently seen ${ }^{17,18}$. Two exceptions to this rule are male patients with CMT1X and patients with HNPP. In these cases, focal demyelination with temporal dispersion or conduction block can be seen. In all other cases of demyelinating CMT, the finding of focal slowing should raise the possibility of a superimposed inflammatory neuropathy, which can benefit from immunosuppressive therapy ${ }^{19}$.

\section{GENETIC TESTING STRATEGIES}

Strategies for focusing genetic testing have been in place since at least 2001, with flow charts to help guide testing ${ }^{20}$. The distribution of causal genes depends at least in part on the population tested. For European and North American populations autosomal recessive (AR) CMT comprises $<10 \%$ of all cases and most patients have dominantly inherited CMT even if their cases are sporadic. Alternatively, populations in which consanguinity is high such as in North Africa may have up to $40 \%$ of their cases being AR. Using MNCV and inheritance patterns, several strategies have been published since the 2001 study, mostly based on North American or European populations ${ }^{21-23}$. We have recently published testing guidelines in which we added age of onset of symptoms to help guide testing ${ }^{24}$. Age of onset classifications was infantile (delayed walking), childhood, or adult. This paper divided MNCV info four categories: $₫ 5 \mathrm{~m} / \mathrm{s}$ (very slow), between 15 and $35 \mathrm{~m} / \mathrm{s}$ (slow), between 35 and $45 \mathrm{~m} / \mathrm{s}$ (intermediate), and over $45 \mathrm{~m} / \mathrm{s}$ (axonal). Flow charts were provided using MNCV as the first level of evidence, with age of onset and inheritance patterns guiding the testing strategy within each category (Figures 2 and 3). In this paper, $92 \%$ of those that had a genetic diagnosis were found to have changes in one of four genes: PMP22, GJB1, MPZ, and MFN2. Thus, the flow diagrams emphasize testing for these types of CMT, excepting HNPP, which has a distinctive nerve conduction study pattern that differs from those of other forms of CMT and should be recognizable. 


\section{MNCV $\leq 15 \mathrm{~m} / \mathrm{s}$ (Figure 2A)}

All people with very slow MNCV that walked by 15 months of age had CMT1A, and thus genetic testing for the PMP22 duplication is warranted for these individuals. Of those that had delayed walking, the majority had CMT1A, but 32\% had CMT1B. Genetic testing for CMT1A and CMT1B is appropriate for people in this category. If these tests are negative, genetic testing for more rare forms of CMT may be reasonable.

\section{MNCV $15<$ and $\leq 35 \mathrm{~m} / \mathrm{s}$ (Figure 2B)}

Approximately $89 \%$ of those with slow MNCV who began walking by 15 months of age had CMT1A, and thus genetic testing should begin with PMP22 duplication analysis. CMT1X was the next most common type of CMT, but should only be performed for people who do not have evidence of male-to-male transmission in their pedigree. CMT1B testing is much less likely to be the cause of the CMT for people in this category, but testing may be reasonable if testing for CMT1A and CMT1X are negative, or if there is evidence of male to male transmission.

\section{MNCV $>35$ and $\leq 45 \mathrm{~m} / \mathrm{s}$ (Figure $3 \mathrm{~A}$ )}

Most people who had intermediate conductions had either CMT1X or CMT1B. If symptoms began in childhood, and no male-to-male transmission is present in the pedigree, it is most likely for the person to have CMT1X. If this testing is negative, CMT1B testing may be pursued. However, if the symptom onset was in adulthood, testing for CMT1B is more likely to elicit a positive genetic testing result, with CMT1X being a reasonable follow up testing.

\section{Axonal CMT: MNCV $>\mathbf{4 5} \mathrm{m} / \mathrm{s}$ or Unobtainable CMAP (Figure 3B)}

People with normal velocities or unobtainable CMAP usually presented with CMT1X (usually females), CMT1B, or CMT2A. Those with unobtainable CMAP were usually those with CMT2A, who are often severely affected in infancy and childhood ${ }^{25}$. Thus, for children with early onset or severe CMT, it is proposed to begin genetic testing for CMT2A. For those with axonal CMT that have a classic or adult onset of symptoms, testing should begin with CMT1X in the absence of male to male transmission in the pedigree and CMT1B if male to male transmission is present or if CMT1X testing is negative. The authors propose using other clinical findings, such as if the upper limbs are more severely affected than the lower limbs, to help guide additional genetic testing if necessary. For these patients, mutations in the $G A R S$ gene, causing CMT2D may be appropriate.

While a detailed review of the pros and cons for testing is beyond the scope of this manuscript, we think it reasonable to provide some information about how we pursue genetic testing ${ }^{26}$. Clearly, not every patient with a genetic neuropathy wants or needs testing to identify the genetic cause of their disease. We believe that the ultimate decision to undergo genetic testing rests with the patient or the patient's parents if a symptomatic child is under 18 years of age. Reasons that patients give for obtaining testing include identifying the inheritance pattern of their CMT, making family planning decisions, and obtaining knowledge about the cause and natural history of their form of CMT. Natural history data is available for some forms of CMT such as CMT1 $\mathrm{A}^{27}$ and CMT1X ${ }^{28}$, which can provide guidance for prognosis, recognizing that there can be phenotypic variability in these subtypes. Patients with other forms of CMT frequently choose to undergo genetic testing to contribute to the natural history data collection for other patients with the same subtype. There are also reasons why patients do not want genetic testing. These include the high costs of commercial testing and fears of discrimination in the workplace or in obtaining health insurance. Since there are currently no medications to reverse any form of CMT, many 
patients decide against testing since their therapies will not depend on the results. We maintain that is always the patient's decision whether or not to pursue genetic testing.

Once a genetic diagnosis has been made in a patient, other family members usually do not need genetic testing but can be identified by clinical evaluation with neurophysiology. We do not typically test patients for multiple genetic causes of CMT simultaneously, although we did identify 11 patients with multiple genetic causes of CMT. It is our current policy to only consider performing genetic testing in clinically affected family members of a proband if their phenotype is atypical for the type of CMT in the family. In addition, we do not test asymptomatic minors with a family history of CMT, either by electrophysiology or genetic testing, due to the chance for increased psychological harm to the child. ${ }^{29}$ We do routinely perform limited nerve conduction studies, though not needle EMG, on symptomatic children with CMT. Since nerve conduction changes, including slowing, are often uniform and detectable in early childhood in CMT ${ }^{17,18}$, testing of a single nerve is often adequate to guide genetic testing or determine whether a symptomatic child is affected in a family with CMT

\section{SPECIFIC FORMS OF CMT}

\section{CMT1}

CMT1 includes five types of CMT that are caused by four genes when mutated. This group includes the majority of people with CMT (over 70\%). These genes are essential to Schwann cell function and the formation of myelin sheaths surrounding the axon, though they interact in different ways and thus are phenoypically heterogeneous ${ }^{30}$.

CMT1A-CMT1A is the most common type of CMT, affecting 55\% of genetically defined patients ${ }^{24}$. It is caused by a $1.4 \mathrm{Mb}$ duplication at $17 \mathrm{p} 11.2$ including the Peripheral Myelin Protein 22 (PMP22) gene, created by unequal crossing over of homologous chromosomes ${ }^{31,32}$. People with CMT1A typically have the "classic" CMT phenotype, with normal age of onset for walking, development of symptoms in the first two decades, pes cavus, slowly progressive motor and sensory neuropathy, rarely progressing to wheelchair use later in life. ${ }^{24,33}$ People with CMT1A have distinctive length dependent sensorimotor demyelinating neuropathies. One study found that $>90 \%$ of patients with CMT1A had MNCV in the ulnar nerve between 16 and $35 \mathrm{~m} / \mathrm{s}$ or less ${ }^{24}$.

CMT1A is an autosomal dominant condition, and most people will have a family history. However, there is a de novo rate of about $10 \% 34$. Therefore, people without family history with ulnar MNCV under $35 \mathrm{~m} / \mathrm{s}$ should first be screened for the PMP22 duplication before proceeding with other genetic testing ${ }^{24}$. Once one person in a family has been genetically shown to have CMT1A, first and second-degree family members can be screened by MNCV. If other family members are shown to have the characteristically slowed conductions, it can be assumed that that person also has CMT1A without needing genetic testing.

\section{Hereditary Neuropathy with liability to Pressure Palsies (HNPP)—HNPP is} caused by the reciprocal deletion of the $1.4 \mathrm{Mb}$ stretch of chromosome $17 \mathrm{p} 11.2$ containing the PMP22 gene ${ }^{35}$. A small percentage of people with HNPP have this phenotype due to a frameshift, splice site, or point mutation of the PMP22 gene (www.molgen.ua.ac.be/ cmtmutations). HNPP is the third most common type of CMT, affecting about $9.1 \%$ of genetically diagnosed patients ${ }^{24}$, with a de novo rate of about $20 \%{ }^{36}$. The hallmark feature of HNPP is transient and recurrent motor and sensory mononeuropathies. These typically occur at entrapment sites, such as the carpal tunnel, ulnar groove, and fibular head ${ }^{37}$. These palsies may last hours, days, or weeks, or occasionally longer. For some people, HNPP can 
progress to long-term peripheral neuropathy phenotypically indistinguishable from CMT1, in which patients may require AFOs or wrist splints ${ }^{37}$. HNPP can be distinguished electrodiagnostically by marked slowing of the ulnar and sural sensory nerve conduction velocities, with or without reduced SNAP, and relatively preserved MNCV ${ }^{38}$. Distal motor latencies, particularly in the median and peroneal nerves, are typically prolonged, often out of proportion with the reduction of velocity ${ }^{39}$. Conduction block and focal slowing often occur at entrapment sites, particularly during a palsy episode ${ }^{37}$.

CMT1B-CMT1B is caused by mutations in the myelin protein zero (MPZ) gene ${ }^{40}$ located at chromosome 1q22, which encodes for MPZ, a major component of the myelin sheath. It affects about $8.5 \%$ of people with genetically defined CMT ${ }^{24}$. People with CMT1B usually present in a bimodal distribution, with one group developing a severe, early onset, demyelinating neuropathy, and the other a late onset, milder, axonal neuropathy. Age of onset of symptoms is useful in determining the subtype of CMT. The majority of those with early onset CMT1B will have delayed walking and MNCV $<15 \mathrm{~m} / \mathrm{s}^{24}$. Those with late onset CMT1B will walk at a normal age and usually have MNCV $>35 \mathrm{~m} / \mathrm{s}^{24}$.

CMT1C-CMT1C is caused by mutations in the SIMPLE gene at chromosome 16p13.3p12 ${ }^{41}$. The phenotype of CMT1C appears to be similar to that of CMT1A, with onset between the first and third decades and MNCV between 16 and $25 \mathrm{~m} / \mathrm{s}^{42,43}$, and progressive sensorimotor nerve involvement. SIMPLE mutations are a rare cause for CMT, making up $0.6-1.2 \%$ of demyelinating CMT cohorts ${ }^{24,42}$.

CMT1D-CMT1D is caused by mutations in the EGR2 gene at chromosome 10q21.1$\mathrm{q} 22.1^{44}$. Patients typically present in infancy with severe symptoms and may have congenital hypomyelination (hypotonia, delayed motor milestones, MNCV $<10 \mathrm{~m} / \mathrm{s}$ ) 45 . Cranial nerve involvement may also be present ${ }^{45,46}$. Recessive inheritance has also been described with this gene causing CMT4E, which appears to have a similar phenotype.

CMT1E-Point mutations in the PMP22 gene cause CMT1E or HNPP, depending on the function of the mutation. Those with CMT1E tend to have earlier onset, more severe symptoms than those with CMT1A but this is not invariable ${ }^{47,48}$. MNCV in severely affected patients are markedly reduced, usually under $10 \mathrm{~m} / \mathrm{s}^{47}$. Onset within the first two years of life presenting with delayed walking is not uncommon. CMT1E is a rare form of CMT, accounting for about $1 \%$ of people with genetically confirmed CMT ${ }^{24}$.

\section{CMT2}

CMT2A-CMT2A is caused by mutations in the MFN2 gene ${ }^{49}$. This is the most common type of CMT2, accounting for approximately $21 \%$ of axonal CMT ${ }^{25}$. People with CMT2A, usually, though not always have a severe phenotype, with onset in infancy or early childhood and usually needing a wheelchair for ambulation by 20 years of age ${ }^{25,49}$. It may be difficult to perform nerve conduction studies and obtain responses for those with severe muscle atrophy, and thus people who have severe symptoms without recordable potentials should be screened for CMT2A. The minority of patients may present with a mild or moderate axonal phenotype ${ }^{25}$. There is a large number of polymorphisms in MFN2 so that care must be taken to ensure that mutations are disease causing. Most disease causing mutations are in the GTPase domain, coiled-coil domains or in other evolutionary conserved regions of the protein 25 .

CMT2B-CMT2B is caused by mutations in the $R A B 7$ gene $^{50}$. This type of CMT is distinguished by distal sensory loss that often leads to foot ulcerations and subsequently infections and amputations $50-53$ in addition to typical motor signs. Nerve conductions are 
often of reduced amplitude with normal or near normal velocities ${ }^{50-53}$. Sensory loss is often severe such that patients may be clinically indistinguishable from those with hereditary sensory and autonomic neuropathy (HSAN) type 1 .

CMT2C-CMT2C is caused by mutations in the TRPV4 gene ${ }^{54-56}$. CMT2C is characterized by motor greater than sensory axonal neuropathy and vocal cord and diaphragm paresis, often presenting with hoarseness or stridor ${ }^{54-57}$. Sensorineural hearing loss and bladder urgency and incontinence have been reported ${ }^{54}$. CMT2C is allelic with spondylometaphyseal dysplasia, metatropic dysplasia, and brachyolmia, and thus may have some overlapping characteristics such as short statures and scoliosis 55,58 .

CMT2D-CMT2D is an axonal neuropathy caused by mutations in the GARS gene ${ }^{59}$. People with CMT2D typically have upper greater than and/or before lower extremity weakness and wasting, with a "split-hand" appearance of more atrophy in the FDI and thenar eminences and less so in the hypothenareminence ${ }^{59,60}$. CMT2D is allelic with distal spinal muscular atrophy type V (dSMA-V), with the distinguishing feature being lack of sensory involvement in dSMA-V ${ }^{60}$.

CMT2E-CMT2E is caused by mutations in the NEFL gene ${ }^{61}$. Nerve conduction studies may be axonal or in the demyelinating range ${ }^{62-64}$. Those with demyelinating conductions may have a severe early onset or a childhood presentation ${ }^{64}$. This is considered an axonal form of CMT since neurofilaments are components of the axon, not myelin ${ }^{65}$.

CMT2F-CMT2F is caused by mutations in the HSPB1 gene, a member of the heat shock protein superfamily, and is also known as HSP27 ${ }^{66}$. Most people with mutations in this gene have distal hereditary motor neuropathy (dHMN), a pure motor phenotype ${ }^{67,68}$, though some will have sensory findings on exam and electrophysiology ${ }^{69}$. Impairment typically begins in the distal legs, and progresses slowly to the distal arms and then proximal legs ${ }^{68}$. There has been one report of presumed autosomal recessive inheritance with mutations in this gene ${ }^{68}$.

CMT2L-CMT2L is caused by mutations in the HSPB8 gene, also a member of the heat shock protein superfamily, and is also known as HSP22 ${ }^{70}$. Mutations in this gene have also been found to cause dHMN type II ${ }^{71}$. Scoliosis and proximal weakness have been reported ${ }^{72}$. Mutations in this gene are a rare cause of CMT.

CMT2K-CMT2K is caused by heterozygous mutations in the GDAP1 gene, though recessive forms of CMT with mutations in this gene are called CMT4A and are likely more common $^{73}$. Thus far, five mutations have been found to cause CMT2K: $358 \mathrm{C}>\mathrm{T}$ (p. R120W) ${ }^{74,75}, 469 \mathrm{~A}>\mathrm{C}$ (p.T157P) $75^{66}, 678 \mathrm{~A}>\mathrm{T}$ (p.R226S) ${ }^{76}, 101 \mathrm{C}>\mathrm{G}$ (p.S34C) ${ }^{76}$, and $23 \mathrm{delAG}$ (p.G10fs) ${ }^{76}$. Phenotypes range from mild adult onset and slowly progressive to severe childhood onset ${ }^{73-76}$. One study found that $3 / 11$ families with CMT2 had a dominantly inherited mutation in $G D A P 1^{76}$, indicating that this may be a significant cause of axonal CMT.

\section{CMT4}

CMT4A-CMT4A is caused by two recessive mutations in the GDAP1 gene ${ }^{73}$. People with CMT4A typically have an early onset, severe, sensorimotor neuropathy ${ }^{73,77}$, that may be demyelinating or axonal in presentation ${ }^{78,79}$. Phenotype is typically severe, with first symptoms being noted in childhood and eventual progression to wheelchair not uncommon 79,80 . Vocal cord paralysis or hoarseness has also been reported ${ }^{79,80}$. Nerve conductions have been described as axonal or demyelinating, which has led to some 
confusion about the cell type of origin for the disease. GDAP1 is a nuclear encoded gene that plays a role in mitochondrial fission or fragmentation, as opposed to $M F N 2$, the causal gene for CMT2A, which plays an important role in mitochondrial fusion.

CMT4B1-CMT4B1 is caused by mutations in the MTMR2 gene ${ }^{81}$. Patients typically have demyelinating $\mathrm{MNCV}^{82}$. Onset is usually in childhood and causes distal weakness that progress proximally, often leading to wheelchair use by adulthood ${ }^{83}$. Diaphragmatic and facial weakness may occur ${ }^{84,85}$.

CMT4B2-CMT4B2 is caused by mutations in $S B F 2$, also known as MTMR1386,87. Nerve conductions are usually demyelinating ${ }^{86,87}$. Onset is typically in childhood, though later than in CMT4B $1{ }^{87}$. Nerve biopsies showing focally folded myelin are characteristic of CMT4B1 (MTMR2 mutations) and CMT4B2 (MTMR13 mutations).

CMT4C-CMT4C is caused by mutations in the $S H 3 T C 2$ gene ${ }^{88}$. In addition to demyelinating sensorimotor neuropathy, scoliosis or kyphoscoliosis is a hallmark feature of this condition ${ }^{88-92}$, though not universally present. Patients often present in childhood with delayed walking, distal weakness, foot deformities, or scoliosis $88-91,93$. Cranial nerve involvements may also be present ${ }^{90,91,93}$. While prevalence numbers are not known in all populations, there is evidence that CMT4C may be the most common of the autosomal recessive inherited neuropathies ${ }^{92}$.

CMT4F-CMT4F is caused by mutations in the PERIAXIN gene $(P R X){ }^{94,95}$. Patients have demyelinating conductions and severe early onset sensorimotor neuropathy ${ }^{94,96}$. Sensory ataxia may be present ${ }^{94,96,97}$, as might scoliosis ${ }^{96}$. Many sequence changes in the $P R X$ gene have been found to be benign variants (www.molgen.ua.ac.be/cmtmutations), and variants of uncertain significance within the gene should be further investigated prior to determining if they are disease-causing mutations.

CMT4J-CMT4J is caused by mutations in the FIG4 gene ${ }^{98}$. Patients may have demyelinating conductions and a severe motor phenotype, possibly asymmetric, with onset in early childhood. Rapid progression to a wheelchair in adulthood has been described for patients that were only mildly affected in their first two decades of life ${ }^{98,99}$. Early death has been reported (47 years of age) ${ }^{99}$. Abnormalities on EMG may be similar to those seen in motor neuron disease, including fibrillations, positive waves, and reduced motor unit action potentials of long durations. However, as mentioned above, NCS may be in the demyelinating range despite these EMG changes ${ }^{99}$.

\section{CMTX}

CMT1X-CMT1X is caused by mutations in the GJB1 gene, encoding the protein CONNEXIN 32 (Cx32) ${ }^{6}$. CMT1X is the second most common form of CMT, found in at least $10 \%$ of all patients ${ }^{24}$. Males typically have more severe symptoms than females with the condition 100 , and tend to have marked atrophy of the intrinsic hand muscles and all compartments of the calf muscles. Most males will have symptoms in childhood, though about $20 \%$ have a later age of onset ${ }^{24}$. Males with CMT1X have been reported to have transient stroke like episodes with MRI changes following a stressor (see ${ }^{101}$ for a review). While $2 / 3$ of females with CMT1X will have slowly progressive mild symptoms, $1 / 3$ do have moderate neuropathy more similar to males with the condition. (Siskind, et al, in press). Male MNCV often present between 25 and $45 \mathrm{~m} / \mathrm{s}$, while females usually have $\mathrm{MNCV}>35 \mathrm{~m} / \mathrm{s}^{24}$. 


\section{Hereditary Sensory and Autonomic Neuropathies (HSAN)}

The hereditary sensory and autonomic neuropathies are characterized by a predominant (although not always exclusive) sensory presentation. Patients may develop distinct clinical phenotypes according to the genetic abnormality, including distal lower limb sensory loss and neuropathic pain, congenital insensitivity to pain or pure autonomic dysfunction. Most HSAN syndromes are autosomal recessive and early-onset, although some can be autosomal dominant. HSAN subtypes are described in table 2.

\section{Distal Hereditary Motor Neuropathies (dHMN)}

This term is used to define inherited neuropathies that are exclusively motor in nature, but are similar to CMT in any other way. Specifically, they are also length-dependent and usually slowly progressive. Some of the dHMN are actually caused by mutation in genes that are also related to CMT. A description of dHMN subtypes and their main features can be found in table 3 .

\section{Inherited neuropathies in multisystem genetic disorders}

Inherited neuropathies can be part of a more generalized genetic disease that affects other neurologic and non-neurologic systems. Examples of genetic neurologic disorders that can present with peripheral neuropathies are the spinocerebellar ataxias (SCAs) and the hereditary spastic paraplegias. Metabolic disorders are another cause of multisystem diseases that also affect the peripheral nervous system. This group includes some leukodystrophies (metachromatic, Krabbe, adrenoleukodystrophy), peroxisomal diseases (Fabry, Refsum), lipoprotein deficiencies (Tangier, Cerebrotendinous xantomathosis), porphyrias, mitochondrial diseases and the familial amyloid neuropathies. A comprehensive review of these conditions is beyond the scope of this paper; however it is important to include this group of diseases in the differential diagnosis of patients with inherited neuropathies and signs of dysfunction beyond the peripheral nervous system.

\section{THERAPEUTICAL STRATEGIES AND FUTURE DIRECTIONS}

Despite the great improvement in our biological understanding of inherited neuropathies, derived mostly from developments in molecular biology and transgenic animal models in the last 25 years, there is still no available treatment for any type of CMT. Physical therapy, occupational therapy and a few orthopedic procedures are still the cornerstone of CMT treatment.

A dedicated, multidisciplinary rehabilitation team can significantly contribute to the management of patients with CMT and improve functionality and quality of life. Physical therapy strategies to maintain muscle strength and tone, prevent muscle contractures and improve balance are a common need for most patients with CMT. Orthotics are also an important component of treating these patients, providing support and improving balance for ambulation. Occupational therapy focused in developing tools and strategies to help patients with activities of daily living will benefit patients with CMT, especially those with hand weakness. Tendon lengthening and tendon transfers can benefit a subset of CMT patients with muscle contractures and tendon shortening and patients with significant weakness in functionally relevant muscles, respectively; however, the optimal timing of such procedures is still controversial.

Reducing the expression of PMP22 in Schwann cells (hence treating the overexpression of PMP22) is a biological strategy being tested to treat CMT1A. High dose Ascorbic Acid (AA; vitamin C) was shown to decrease pmp22 levels and symptoms in mice with CMT1A, so that they were able to stay on a rotating rod longer, cross a beam more rapidly, and grip 
for longer than untreated mice ${ }^{102}$. Several studies have been performed in humans with CMT1A, testing different doses of vitamin C (1-4 g/day) for up to two years. Unfortunately, all studies failed to meet their primary outcome measures and did not show a significant effect on phenotype ${ }^{103-106}$. Progesterone antagonists have also been shown to decrease pmp22 expression in a rat model of CMT1A, improving their phenotype (specifically, the axonal loss seen during disease progression) ${ }^{107,108}$. Unfortunately, onapristone, the compound shown to have therapeutical effects in this study, is toxic to humans. Efforts to develop bioequivalent compounds with a better safety profile are ongoing.

Recent studies have demonstrated the role of endoplasmic reticulum (ER) accumulation of misfolded proteins and unfolded protein response activation in the pathogenesis of several animal models of CMT associated with point mutations in myelin-related genes, including pmp $22^{8}$ and $m p z^{9,10}$. Furthermore, treatment with an agent that relieves ER stress (curcumin) improved the phenotype of both models ${ }^{11,12}$. Therefore, compounds that either relieve ER stress or reduced UPR activation are promising therapeutical strategies to treat patients with mutations that cause misfolded proteins to accumulate in the ER of Schwann Cells.

Treatment strategies for axonal forms of CMT have not been as easily identified as for demyelinating forms. Recently, HDAC6 inhibitors have been shown to correct axonal transport defects in a mouse model of CMT2F associated with point mutations in the HSPB1 gene, rescuing the axonal loss and clinical phenotype of these mice ${ }^{109}$. It remains to be shown whether this same strategy could be useful in other forms of axonal CMT, but correcting axonal transport defects may be a common treatment option for most of these CMT types.

Two new technologies recently developed hold enormous potential in the search for compounds to treat CMT: cellular reprogramming and high throughput drug screening. Cellular reprogramming is a technique that allows the generation of specific cell types (including stem cell-like cells, neurons and glia) by genetically modifying readily available somatic cells such as fibroblasts or lymphocytes 110,111 . Using this technology, researchers are able to generate unlimited supplies of patient-specific cell lines for use in mechanistic studies and drug development ${ }^{112}$. These patient-specific cells lines will be particularly useful when combined with high throughput screening of drug libraries containing thousands of compounds. In these highly automated platforms, the process of identifying compounds capable of correcting certain disease-related cell phenotypes is streamlined, allowing for a faster target selection of compounds to be tested in phase 1 animal studies. The use of patient-derived human cells offer the theoretical advantage of a more translational platform, which could facilitate the process of moving from phase 1 studies to human clinical trials. Whether this is actually true, remains to be proven. A recent study using cellular reprogramming successfully generated human neural crest progenitors derived from a patient with HSAN type III ${ }^{113}$. These cells are the precursors of sensory and autonomic neurons, the cell types most affected by this condition. Interestingly, patientderived neural crest precursors expressed very low levels of normal IKBKAP transcript, while also displaying marked defects in neuronal differentiation and migration. The authors were also able to find compounds that at least partially rescued this phenotype, validating this platform for drug discovery in inherited neuropathies.

\section{CONCLUSION}

While CMT is a genetically heterogeneous condition, it is often possible to determine the type of CMT a person has by distinguishing characteristics. The prevalence of the various mutations, inheritance pattern, nerve conductions, and age of onset should be taken into 
account when deciding what genetic testing should be ordered. New genes causing CMT continue to be found, prevalence continues to be studied, and recommendations for testing will continue to evolve over time. Our increasing understanding of biological processes involved in CMT has offered new therapeutical targets for drug development and new tools recently developed hold the promise of even faster drug discovery in CMT.

\section{Acknowledgments}

M.E.S. is supported in part by research grants from the NINDS/ORD, Muscular Dystrophy Association and the Charcot Marie Tooth Association. The authors would like to thank Luis Saporta for artwork prepared for this manuscript.

\section{REFERENCES}

1. Skre H. Genetic and clinical aspects of Charcot-Marie-Tooth's disease. Clinical genetics. 1974; 6(2):98-118. [PubMed: 4430158]

2. Dyck PJ, Oviatt KF, Lambert EH. Intensive evaluation of referred unclassified neuropathies yields improved diagnosis. Ann Neurol. 1981; 10:222-226. [PubMed: 7294727]

3. Trapp, BD.; Pfeiffer, SE.; Anitei, A.; Kidd, GJ. Cell Biology and myelin assembly. In: Lazzarini, RA., editor. Myelin Biology and Disorders. Elsevier Academic Press; San Diego/London: 2003. p. 29-56.

4. Niemann A, Berger P, Suter U. Pathomechanisms of mutant proteins in Charcot-Marie-Tooth disease. Neuromolecular medicine. 2006; 8(1-2):217-242. [PubMed: 16775378]

5. Li J. Hypothesis of double polarization. Journal of the neurological sciences. 2008; 275(1-2):33-36. [PubMed: 18706661]

6. Bergoffen J, Scherer SS, Wang S, et al. Connexin mutations in X-linked Charcot-Marie-Tooth disease. Science. 1993; 262(5142):2039-2042. [PubMed: 8266101]

7. Krajewski KM, Lewis RA, Fuerst DR, et al. Neurological dysfunction and axonal degeneration in Charcot-Marie-Tooth disease type 1A. Brain. 2000; 123(7):1516-1527. [PubMed: 10869062]

8. Colby J, Nicholson R, Dickson KM, et al. PMP22 carrying the trembler or trembler-J mutation is intracellularly retained in myelinating Schwann cells. Neurobiol Dis. 2000; 7:561-573. [PubMed: 11114256]

9. Pennuto M, Tinelli E, Malaguti M, et al. Ablation of the UPRMediator CHOP Restores Motor Function and Reduces Demyelination in Charcot-Marie-Tooth 1BMice. Neuron. 2008; 57:393-405. [PubMed: 18255032]

10. Saporta MA, Shy BR, Patzko A, et al. MpzR98C arrests Schwann cell development in a mouse model of early-onset Charcot-Marie-Tooth disease type 1B. Brain. 2012; 135(7):2032-2047. [PubMed: 22689911]

11. Khajavi M, Shiga K, Wiszniewski W, et al. Oral curcumin mitigates the clinical and neuropathologic phenotype of the Trembler-J mouse: a potential therapy for inherited neuropathy. Am J Hum Genet. 2007; 81:438-453. [PubMed: 17701891]

12. Patzko A, Bai Y, Saporta M, et al. Curcumin derivatives promote Schwann cell differentiation and improve neuropathy in R98C CMT1B mice. Brain. 2012; 135(12):3551-3566. [PubMed: 23250879]

13. Harding AE, Thomas PK. Genetic aspects of hereditary motor and sensory neuropathy (types I and II). Journal of medical genetics. 1980; 17(5):329-336. [PubMed: 7218272]

14. Harding AE, Thomas PK. The clinical features of hereditary motor and sensory neuropathy types I and II. Brain. 1980; 103(2):259-280. [PubMed: 7397478]

15. Thomas PK, Harding AE. Inherited neuropathies: the interface between molecular genetics and pathology. Brain Pathol. 1993; 3(2):129-133. [PubMed: 8293174]

16. Michels, VV.; Dyck, PJ. Mendelian Inheritance and Basis of Classification of Hereditary Neuropathy with Neuronal Atrophy and Degeneration. In: Dyck, P.; Thomas, PK.; Lambert, EH.; Bunge, R., editors. Peripheral Neuropathy Second Edition. W.B. Saunders Company; Philadelphia: 1984. p. 1512-1524. 
17. Lewis RA, Sumner AJ. The electrodiagnostic distinctions between chronic familial and acquired demyelinative neuropathies. Neurology. 1982; 32(6):592-596. [PubMed: 6283420]

18. Lewis RA, Sumner AJ, Shy ME. Electrophysiological features of inherited demyelinating neuropathies: A reappraisal in the era of molecular diagnosis. Muscle \& nerve. 2000; 23(10): 1472-1487. [PubMed: 11003782]

19. Ginsberg L, Malik O, Kenton AR, et al. Coexistent hereditary and inflammatory neuropathy. Brain. 2004; 127(1):193-202. [PubMed: 14607795]

20. Dubourg O, Tardieu S, Birouk N, et al. The frequency of $17 \mathrm{p} 11.2$ duplication and Connexin 32 mutations in 282 Charcot-Marie-Tooth families in relation to the mode of inheritance and motor nerve conduction velocity. Neuromuscular disorders: NMD. 2001; 11(5):458-463. [PubMed: 11404117]

21. England JD, Gronseth GS, Franklin G, et al. Practice parameter: the evaluation of distal symmetric polyneuropathy: the role of laboratory and genetic testing (an evidence-based review). Report of the American Academy of Neurology, the American Association of Neuromuscular and Electrodiagnostic Medicine, and the American Academy of Physical Medicine and Rehabilitation. PM R. 2009; 1(1):5-13. [PubMed: 19627867]

22. England JD, Gronseth GS, Franklin G, et al. Practice Parameter: evaluation of distal symmetric polyneuropathy: role of laboratory and genetic testing (an evidence-based review). Report of the American Academy of Neurology, American Association of Neuromuscular and Electrodiagnostic Medicine, and American Academy of Physical Medicine and Rehabilitation. Neurology. 2009; 72(2):185-192. [PubMed: 19056666]

23. Burgunder JM, Schols L, Baets J, et al. EFNS guidelines for the molecular diagnosis of neurogenetic disorders: motoneuron, peripheral nerve and muscle disorders. Eur J Neurol. 2011; 18(2):207-217. [PubMed: 20500522]

24. Saporta AS, Sottile SL, Miller LJ, et al. Charcot-marie-tooth disease subtypes and genetic testing strategies. Ann Neurol. 2011; 69(1):22-33. [PubMed: 21280073]

25. Feely SM, Laura M, Siskind CE, et al. MFN2 mutations cause severe phenotypes in most patients with CMT2A. Neurology. 2011; 76(20):1690-1696. [PubMed: 21508331]

26. Krajewski KM, Shy ME. Genetic testing in neuromuscular disease. Neurol Clin. 2004; 22(3):481508. v. [PubMed: 15207873]

27. Shy ME, Chen L, Swan ER, et al. Neuropathy progression in Charcot-Marie-Tooth disease type 1A. Neurology. 2008; 70(5):378-383. [PubMed: 18227419]

28. Shy ME, Siskind C, Swan ER, et al. CMT1X phenotypes represent loss of GJB1 gene function. Neurology. 2007; 68(11):849-855. [PubMed: 17353473]

29. American Society of Human Genetics Board of Directors; American College of Medical Genetics Board of Directors. Points to consider: ethical, legal, and psychosocial implications of genetic testing in children and adolescents. Am J Hum Genet. 1995; 57(5):1233-1241. [PubMed: 7485175]

30. Kamholz J, Menichella D, Jani A, et al. Charcot-Marie-Tooth disease type 1: molecular pathogenesis to gene therapy. Brain. 2000; 123(Pt 2):222-233. [PubMed: 10648431]

31. Lupski JR, de Oca-Luna RM, Slaugenhaupt S, et al. DNA duplication associated with CharcotMarie-Tooth disease type 1A. Cell. 1991; 66(2):219-232. [PubMed: 1677316]

32. Raeymaekers P, Timmerman V, Nelis E, et al. The HMSN Collaborative Research Group. Duplication in chromosome 17p11.2 in Charcot-Marie-Tooth neuropathy type 1a (CMT 1a). Neuromuscular disorders: NMD. 1991; 1(2):93-97. [PubMed: 1822787]

33. Sheth S, Francies K, Siskind CE, et al. Diabetes mellitus exacerbates motor and sensory impairment in CMT1A. J Peripher Nerv Syst. 2008; 13(4):299-304. [PubMed: 19192070]

34. Blair IP, Nash J, Gordon MJ, Nicholson GA. Prevalence and origin of de novo duplications in Charcot-Marie-Tooth disease type 1A: first report of a de novo duplication with a maternal origin. American journal of human genetics. 1996; 58(3):472-476. [PubMed: 8644705]

35. Chance PF, Alderson MK, Leppig KA, et al. DNA deletion associated with hereditary neuropathy with liability to pressure palsies. Cell. 1993; 72(1):143-151. [PubMed: 8422677] 
36. Infante J, Garcia A, Combarros O, et al. Diagnostic strategy for familial and sporadic cases of neuropathy associated with 17p11.2 deletion. Muscle Nerve. 2001; 24(9):1149-1155. [PubMed: 11494267]

37. Stogbauer F, Young P, Kuhlenbaumer G, De Jonghe P, Timmerman V. Hereditary recurrent focal neuropathies: clinical and molecular features. Neurology. 2000; 54(3):546-551. [PubMed: 10680781]

38. Andersson PB, Yuen E, Parko K, So YT. Electrodiagnostic features of hereditary neuropathy with liability to pressure palsies. Neurology. 2000; 54(1):40-44. [PubMed: 10636123]

39. Li J, Krajewski K, Shy ME, Lewis RA. Hereditary neuropathy with liability to pressure palsy: the electrophysiology fits the name. Neurology. 2002; 58(12):1769-1773. [PubMed: 12084875]

40. Hayasaka K, Himoro M, Sato W, et al. Charcot-Marie-Tooth neuropathy type 1B is associated with mutations of the myelin P0 gene. Nature genetics. 1993; 5(1):31-34. [PubMed: 7693129]

41. Street VA, Bennett CL, Goldy JD, et al. Mutation of a putative protein degradation gene LITAF/ SIMPLE in Charcot-Marie-Tooth disease 1C. Neurology. 2003; 60(1):22-26. [PubMed: 12525712]

42. Latour P, Gonnaud PM, Ollagnon E, et al. SIMPLE mutation analysis in dominant demyelinating Charcot-Marie-Tooth disease: three novel mutations. Journal of the peripheral nervous system: JPNS. 2006; 11(2):148-155. [PubMed: 16787513]

43. Saifi GM, Szigeti K, Wiszniewski W, et al. SIMPLE mutations in Charcot-Marie-Tooth disease and the potential role of its protein product in protein degradation. Human mutation. 2005; 25(4): 372-383. [PubMed: 15776429]

44. Warner LE, Mancias P, Butler IJ, et al. Mutations in the early growth response 2 (EGR2) gene are associated with hereditary myelinopathies. Nature genetics. 1998; 18(4):382-384. [PubMed: 9537424]

45. Vandenberghe N, Upadhyaya M, Gatignol A, et al. Frequency of mutations in the early growth response 2 gene associated with peripheral demyelinating neuropathies. J Med Genet. 2002; 39(12):e81. [PubMed: 12471219]

46. Pareyson D, Taroni F, Botti S, et al. Cranial nerve involvement in CMT disease type 1 due to early growth response 2 gene mutation. Neurology. 2000; 54(8):1696-1698. [PubMed: 10762521]

47. Boerkoel CF, Takashima H, Garcia CA, et al. Charcot-Marie-Tooth disease and related neuropathies: mutation distribution and genotype-phenotype correlation. Annals of neurology. 2002; 51(2):190-201. [PubMed: 11835375]

48. Russo M, Laura M, Polke JM, et al. Variable phenotypes are associated with PMP22 missense mutations. Neuromuscul Disord. 2011; 21(2):106-114. [PubMed: 21194947]

49. Zuchner S, Mersiyanova IV, Muglia M, et al. Mutations in the mitochondrial GTPase mitofusin 2 cause Charcot-Marie-Tooth neuropathy type 2A. Nature genetics. 2004; 36(5):449-451. [PubMed: 15064763]

50. Verhoeven K, De Jonghe P, Coen K, et al. Mutations in the small GTP-ase late endosomal protein RAB7 cause Charcot-Marie-Tooth type 2B neuropathy. American journal of human genetics. 2003; 72(3):722-727. [PubMed: 12545426]

51. Auer-Grumbach M, De Jonghe P, Wagner K, et al. Phenotype-genotype correlations in a CMT2B family with refined 3q13-q22 locus. Neurology. 2000; 55(10):1552-1557. [PubMed: 11094113]

52. De Jonghe P, Timmerman V, FitzPatrick D, et al. Mutilating neuropathic ulcerations in a chromosome 3q13-q22 linked Charcot-Marie-Tooth disease type 2B family. Journal of neurology, neurosurgery, and psychiatry. 1997; 62(6):570-573.

53. Kwon JM, Elliott JL, Yee WC, et al. Assignment of a second Charcot-Marie-Tooth type II locus to chromosome 3q. American journal of human genetics. 1995; 57(4):853-858. [PubMed: 7573046]

54. Landoure G, Zdebik AA, Martinez TL, et al. Mutations in TRPV4 cause Charcot-Marie-Tooth disease type 2C. Nat Genet. 2010; 42(2):170-174. [PubMed: 20037586]

55. Chen DH, Sul Y, Weiss M, et al. CMT2C with vocal cord paresis associated with short stature and mutations in the TRPV4 gene. Neurology. 2010; 75(22):1968-1975. [PubMed: 21115951]

56. Deng HX, Klein CJ, Yan J, et al. Scapuloperoneal spinal muscular atrophy and CMT2C are allelic disorders caused by alterations in TRPV4. Nat Genet. 2010; 42(2):165-169. [PubMed: 20037587] 
57. Dyck PJ, Litchy WJ, Minnerath S, et al. Hereditary motor and sensory neuropathy with diaphragm and vocal cord paresis. Ann Neurol. 1994; 35(5):608-615. [PubMed: 8179305]

58. Klein CJ, Cunningham JM, Atkinson EJ, et al. The gene for HMSN2C maps to 12q23-24: a region of neuromuscular disorders. Neurology. 2003; 60(7):1151-1156. [PubMed: 12682323]

59. Antonellis A, Ellsworth RE, Sambuughin N, et al. Glycyl tRNA synthetase mutations in CharcotMarie-Tooth disease type 2D and distal spinal muscular atrophy type V. American journal of human genetics. 2003; 72(5):1293-1299. [PubMed: 12690580]

60. Sivakumar K, Kyriakides T, Puls I, et al. Phenotypic spectrum of disorders associated with glycyltRNA synthetase mutations. Brain. 2005; 128(Pt 10):2304-2314. [PubMed: 16014653]

61. Mersiyanova IV, Perepelov AV, Polyakov AV, et al. A new variant of Charcot-Marie-Tooth disease type 2 is probably the result of a mutation in the neurofilament-light gene. American journal of human genetics. 2000; 67(1):37-46. [PubMed: 10841809]

62. Georgiou DM, Zidar J, Korosec M, et al. A novel NF-L mutation Pro22Ser is associated with CMT2 in a large Slovenian family. Neurogenetics. 2002; 4(2):93-96. [PubMed: 12481988]

63. Yoshihara T, Yamamoto M, Hattori N, et al. Identification of novel sequence variants in the neurofilament-light gene in a Japanese population: analysis of Charcot-Marie-Tooth disease patients and normal individuals. Journal of the peripheral nervous system: JPNS. 2002; 7(4):221224. [PubMed: 12477167]

64. Jordanova A, De Jonghe P, Boerkoel CF, et al. Mutations in the neurofilament light chain gene (NEFL) cause early onset severe Charcot-Marie-Tooth disease. Brain. 2003; 126(Pt 3):590-597. [PubMed: 12566280]

65. Perez-Olle R, Leung CL, Liem RK. Effects of Charcot-Marie-Tooth-linked mutations of the neurofilament light subunit on intermediate filament formation. Journal of cell science. 2002; 115(Pt 24):4937-4946. [PubMed: 12432080]

66. Evgrafov OV, Mersiyanova I, Irobi J, et al. Mutant small heat-shock protein 27 causes axonal Charcot-Marie-Tooth disease and distal hereditary motor neuropathy. Nature genetics. 2004; 36(6):602-606. [PubMed: 15122254]

67. Chung KW, Kim SB, Cho SY, et al. Distal hereditary motor neuropathy in Korean patients with a small heat shock protein 27 mutation. Exp Mol Med. 2008; 40(3):304-312. [PubMed: 18587268]

68. Houlden H, Laura M, Wavrant-De Vrieze F, et al. Mutations in the HSP27 (HSPB1) gene cause dominant, recessive, and sporadic distal HMN/CMT type 2. Neurology. 2008; 71(21):1660-1668. [PubMed: 18832141]

69. Solla P, Vannelli A, Bolino A, et al. Heat shock protein 27 R127W mutation: evidence of a continuum between axonal Charcot-Marie-Tooth and distal hereditary motor neuropathy. J Neurol Neurosurg Psychiatry. 2010; 81(9):958-962. [PubMed: 20660910]

70. Tang BS, Zhao GH, Luo W, et al. Small heat-shock protein 22 mutated in autosomal dominant Charcot-Marie-Tooth disease type 2L. Human genetics. 2005; 116(3):222-224. [PubMed: 15565283]

71. Irobi J, Van Impe K, Seeman P, et al. Hot-spot residue in small heat-shock protein 22 causes distal motor neuropathy. Nature genetics. 2004; 36(6):597-601. [PubMed: 15122253]

72. Tang BS, Luo W, Xia K, et al. A new locus for autosomal dominant Charcot-Marie-Tooth disease type 2 (CMT2L) maps to chromosome 12q24. Human genetics. 2004; 114(6):527-533. [PubMed: 15021985]

73. Baxter RV, Ben Othmane K, Rochelle JM, et al. Ganglioside-induced differentiation-associated protein-1 is mutant in Charcot-Marie-Tooth disease type 4A/8q21. Nature genetics. 2002; 30(1): 21-22. [PubMed: 11743579]

74. Sivera R, Espinos C, Vilchez JJ, et al. Phenotypical features of the p.R120W mutation in the GDAP1 gene causing autosomal dominant Charcot-Marie-Tooth disease. J Peripher Nerv Syst. 2010; 15(4):334-344. [PubMed: 21199105]

75. Claramunt R, Pedrola L, Sevilla T, et al. Genetics of Charcot-Marie-Tooth disease type 4A: mutations, inheritance, phenotypic variability, and founder effect. Journal of medical genetics. 2005; 42(4):358-365. [PubMed: 15805163] 
76. Crimella C, Tonelli A, Airoldi G, et al. The GST domain of GDAP1 is a frequent target of mutations in the dominant form of axonal Charcot Marie Tooth type $2 \mathrm{~K}$. Journal of medical genetics. 2010; 47(10):712-716. [PubMed: 20685671]

77. Senderek J, Bergmann C, Ramaekers VT, et al. Mutations in the ganglioside-induced differentiation-associated protein-1 (GDAP1) gene in intermediate type autosomal recessive Charcot-Marie-Tooth neuropathy. Brain. 2003; 126(Pt 3):642-649. [PubMed: 12566285]

78. Nelis E, Erdem S, Van Den Bergh PY, et al. Mutations in GDAP1: autosomal recessive CMT with demyelination and axonopathy. Neurology. 2002; 59(12):1865-1872. [PubMed: 12499475]

79. Sevilla T, Cuesta A, Chumillas MJ, et al. Clinical, electrophysiological and morphological findings of Charcot-Marie-Tooth neuropathy with vocal cord palsy and mutations in the GDAP1 gene. Brain. 2003; 126(Pt 9):2023-2033. [PubMed: 12821518]

80. Boerkoel CF, Takashima H, Nakagawa M, et al. CMT4A: identification of a Hispanic GDAP1 founder mutation. Ann Neurol. 2003; 53(3):400-405. [PubMed: 12601710]

81. Bolino A, Muglia M, Conforti FL, et al. Charcot-Marie-Tooth type 4B is caused by mutations in the gene encoding myotubularin-related protein-2. Nature genetics. 2000; 25(1):17-19. [PubMed: 10802647]

82. Houlden H, King RH, Wood NW, Thomas PK, Reilly MM. Mutations in the $5^{\prime}$ region of the myotubularin-related protein 2 (MTMR2) gene in autosomal recessive hereditary neuropathy with focally folded myelin. Brain. 2001; 124(Pt 5):907-915. [PubMed: 11335693]

83. Parman Y, Battaloglu E, Baris I, et al. Clinicopathological and genetic study of early-onset demyelinating neuropathy. Brain. 2004; 127(Pt 11):2540-2550. [PubMed: 15469949]

84. Tyson J, Ellis D, Fairbrother U, et al. Hereditary demyelinating neuropathy of infancy. A genetically complex syndrome. Brain. 1997; 120(Pt 1):47-63. [PubMed: 9055797]

85. Verny C, Ravise N, Leutenegger AL, et al. Coincidence of two genetic forms of Charcot-MarieTooth disease in a single family. Neurology. 2004; 63(8):1527-1529. [PubMed: 15505184]

86. Senderek J, Bergmann C, Weber S, et al. Mutation of the SBF2 gene, encoding a novel member of the myotubularin family, in Charcot-Marie-Tooth neuropathy type 4B2/11p15. Human molecular genetics. 2003; 12(3):349-356. [PubMed: 12554688]

87. Azzedine H, Bolino A, Taieb T, et al. Mutations in MTMR13, a new pseudophosphatase homologue of MTMR2 and Sbf1, in two families with an autosomal recessive demyelinating form of Charcot-Marie-Tooth disease associated with early-onset glaucoma. American journal of human genetics. 2003; 72(5):1141-1153. [PubMed: 12687498]

88. Senderek J, Bergmann C, Stendel C, et al. Mutations in a gene encoding a novel SH3/TPR domain protein cause autosomal recessive Charcot-Marie-Tooth type 4C neuropathy. American journal of human genetics. 2003; 73(5):1106-1119. [PubMed: 14574644]

89. Gooding R, Colomer J, King R, et al. A novel Gypsy founder mutation, p.Arg1109X in the CMT4C gene, causes variable peripheral neuropathy phenotypes. Journal of medical genetics. 2005; 42(12):e69. [PubMed: 16326826]

90. Colomer J, Gooding R, Angelicheva D, et al. Clinical spectrum of CMT4C disease in patients homozygous for the p.Arg1109X mutation in SH3TC2. Neuromuscular disorders: NMD. 2006; 16(7):449-453. [PubMed: 16806930]

91. Azzedine H, Ravise N, Verny C, et al. Spine deformities in Charcot-Marie-Tooth 4C caused by SH3TC2 gene mutations. Neurology. 2006; 67(4):602-606. [PubMed: 16924012]

92. Lassuthova P, Mazanec R, Vondracek P, et al. High frequency of SH3TC2 mutations in Czech HMSN I patients. Clinical genetics. 2011

93. Houlden H, Laura M, Ginsberg L, et al. The phenotype of Charcot-Marie-Tooth disease type 4C due to SH3TC2 mutations and possible predisposition to an inflammatory neuropathy. Neuromuscul Disord. 2009; 19(4):264-269. [PubMed: 19272779]

94. Boerkoel CF, Takashima H, Stankiewicz P, et al. Periaxin mutations cause recessive DejerineSottas neuropathy. American journal of human genetics. 2001; 68(2):325-333. [PubMed: 11133365]

95. Guilbot A, Williams A, Ravise N, et al. A mutation in periaxin is responsible for CMT4F, an autosomal recessive form of Charcot-Marie-Tooth disease. Human molecular genetics. 2001; 10(4):415-421. [PubMed: 11157804] 
96. Marchesi C, Milani M, Morbin M, et al. Four novel cases of periaxin-related neuropathy and review of the literature. Neurology. 2010; 75(20):1830-1838. [PubMed: 21079185]

97. Kabzinska D, Drac H, Sherman DL, et al. Charcot-Marie-Tooth type 4F disease caused by S399fsx410 mutation in the PRX gene. Neurology. 2006; 66(5):745-747. [PubMed: 16534116]

98. Chow CY, Zhang Y, Dowling JJ, et al. Mutation of FIG4 causes neurodegeneration in the pale tremor mouse and patients with CMT4J. Nature. 2007; 448(7149):68-72. [PubMed: 17572665]

99. Zhang X, Chow CY, Sahenk Z, et al. Mutation of FIG4 causes a rapidly progressive, asymmetric neuronal degeneration. Brain. 2008; 131(Pt 8):1990-2001. [PubMed: 18556664]

100. Siskind C, Murphy SM, Ovens R, et al. Phenotype Expression in Women with CMT1X. JPNS. 2011 in press.

101. Siskind C, Feely SM, Bernes S, Shy ME, Garbern JY. Persistent CNS dysfunction in a boy with CMT1X. Journal of the neurological sciences. 2009; 279(1-2):109-113. [PubMed: 19193385]

102. Passage E, Norreel JC, Noack-Fraissignes P, et al. Ascorbic acid treatment corrects the phenotype of a mouse model of Charcot-Marie-Tooth disease. Nature medicine. 2004; 10(4):396-401.

103. Verhamme C, de Haan RJ, Vermeulen M, et al. Oral high dose ascorbic acid treatment for one year in young CMT1A patients: a randomised, double-blind, placebo-controlled phase II trial. BMC Med. 2009; 7:70. [PubMed: 19909499]

104. Burns J, Ouvrier RA, Yiu EM, et al. Ascorbic acid for Charcot-Marie-Tooth disease type 1A in children: a randomised, double-blind, placebo-controlled, safety and efficacy trial. Lancet neurology. 2009; 8(6):537-544. [PubMed: 19427269]

105. Micallef J, Attarian S, Dubourg O, et al. Effect of ascorbic acid in patients with Charcot-MarieTooth disease type 1A: a multicentre, randomised, double-blind, placebo-controlled trial. Lancet neurology. 2009; 8(12):1103-1110. [PubMed: 19818690]

106. Pareyson D, Reilly MM, Schenone A, et al. Ascorbic acid in Charcot-Marie-Tooth disease type 1A (CMT-TRIAAL and CMT-TRAUK): a double-blind randomised trial. Lancet neurology. 2011; 10(4):320-328. [PubMed: 21393063]

107. Sereda MW, Meyer zu Hörste G, Suter U, et al. Therapeutic administration of progesterone antagonist in a model of Charcot-Marie-Tooth disease (CMT-1A). Nat Med. 2003; 9(12):15331537. [PubMed: 14608378]

108. Meyer zu Hörste G, Prukop T, Liebetanz D, et al. Antiprogesterone therapy uncouples axonal loss from demyelination in a transgenic rat model of CMT1A neuropathy. Ann Neurol. 2007; 61(1): 61-72. [PubMed: 17262851]

109. d'Ydewalle C, Krishnan J, Chiheb DM, et al. HDAC6 inhibitors reverse axonal loss in a mouse model of mutant HSPB1-induced Charcot-Marie-Tooth disease. Nat Med. 2011; 17(8):968-974. [PubMed: 21785432]

110. Takahashi K, Yamanaka S. Induction of pluripotent stem cells from mouse embryonic and adult fibroblast cultures by defined factors. Cell. 2006; 126(4):663-676. [PubMed: 16904174]

111. Dimos JT, Rodolfa KT, Niakan KK, et al. Induced pluripotent stem cells generated from patients with ALS can be differentiated into motor neurons. Science. 2008; 321(5893):1218-1221. [PubMed: 18669821]

112. Saporta MA, Grskovic M, Dimos JT. Induced pluripotent stem cells in the study of neurological diseases. Stem Cell Res Ther. 2011; 2(5):37. [PubMed: 21936964]

113. Lee G, Papapetrou EP, Kim H, et al. Modelling pathogenesis and treatment of familial dysautonomia using patient-specific IPSCs. Nature. 2009; 461(7262):402-406. [PubMed: 19693009]

114. Reilly MM, Shy ME. Diagnosis and new treatments in genetic neuropathies. J Neurol Neurosurg Psychiatry. 2009; 80(12):1304-1314. [PubMed: 19917815] 


\section{KEY POINTS}

1. Identifiable genetic causes of neuropathy elucidate biological pathways that cause demyelination or axonal loss.

2. Charcot Marie Tooth disease is genetically and clinically heterogeneous with $>50$ genes causing neuropathy that can vary in age of onset and severity.

3. Mutations in just 4 genes (PMP22, GJB1, MPZ and MFN2) cause $>90 \%$ of the genetically identifiable cases of CMT in North America.

4. Combining the clinical phenotype and nerve conduction velocities in the arm can further focus genetic testing among these four genes.

5. Because CMT can affect family members other than the proband we suggest that genetic counseling be considered for patients and their families 


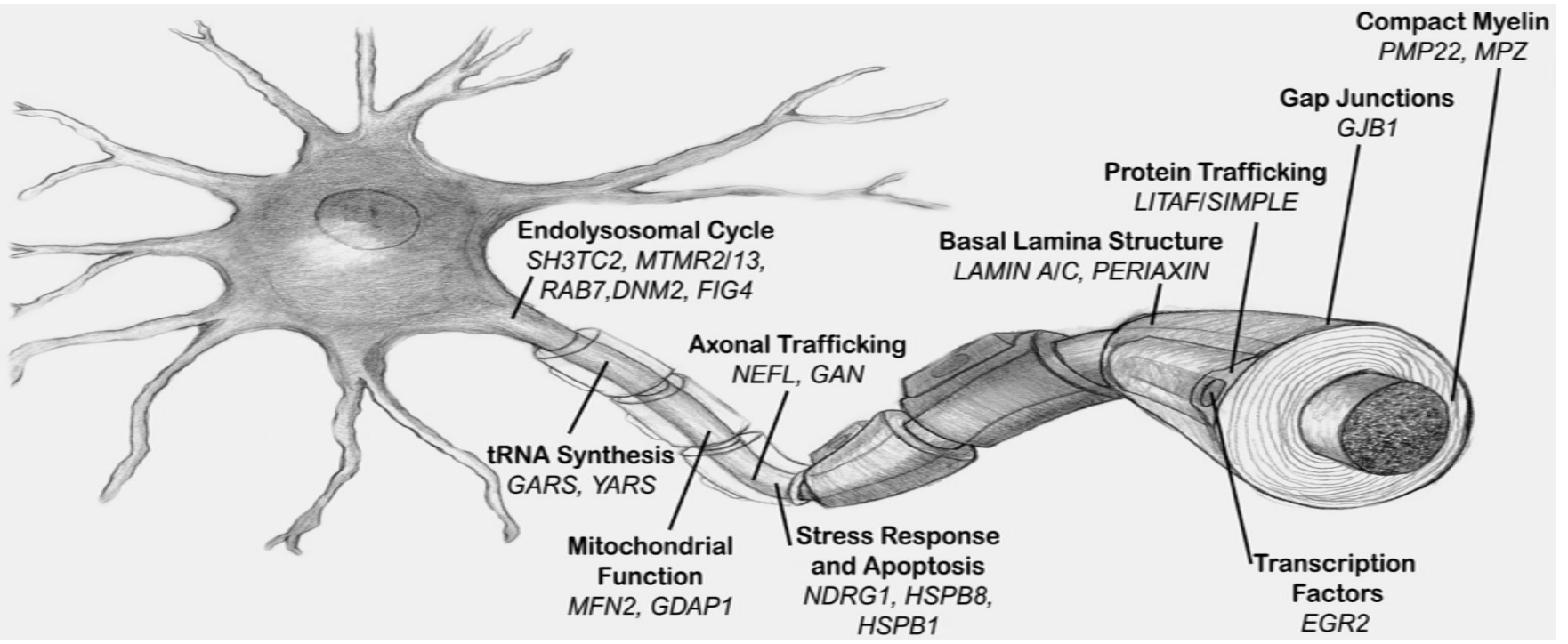

Figure 1.

Schematic drawing of a neuron, its axon and Schwann cells with the major genes associated with Charcot-Marie-Tooth disease represented with their respective function and cellular compartment. 


\section{Slow MNCV $(15<$ and $\leq 35 \mathrm{~m} / \mathrm{s})$}

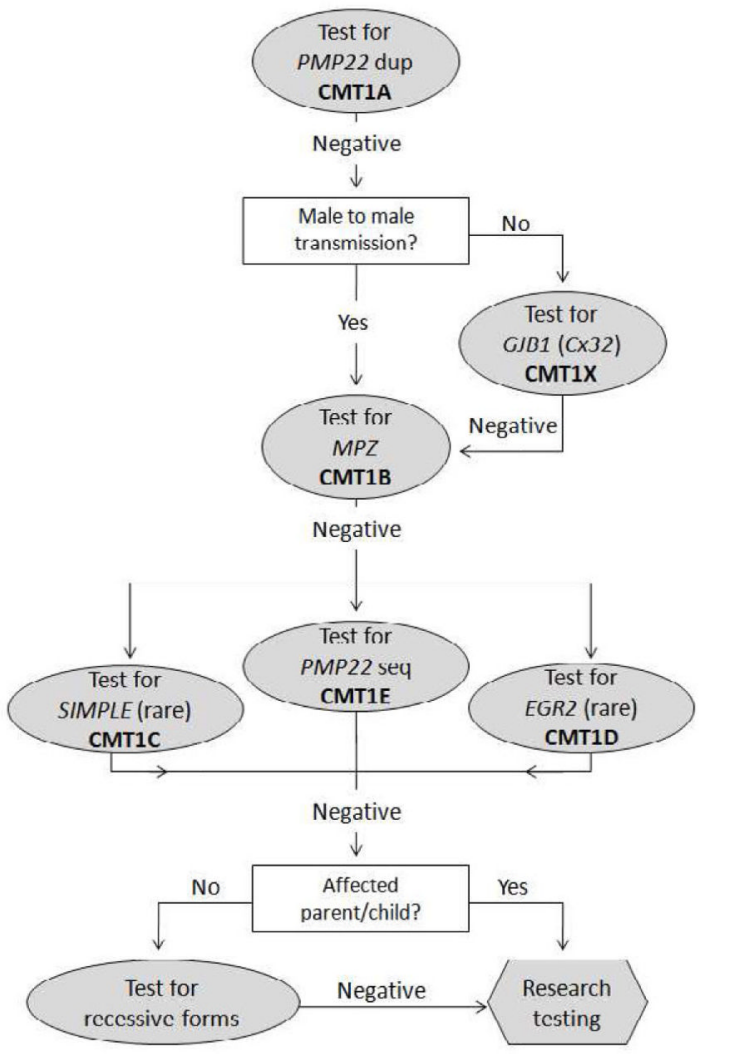

\section{Very slow MNCV $(\leq 15 \mathrm{~m} / \mathrm{s})$}
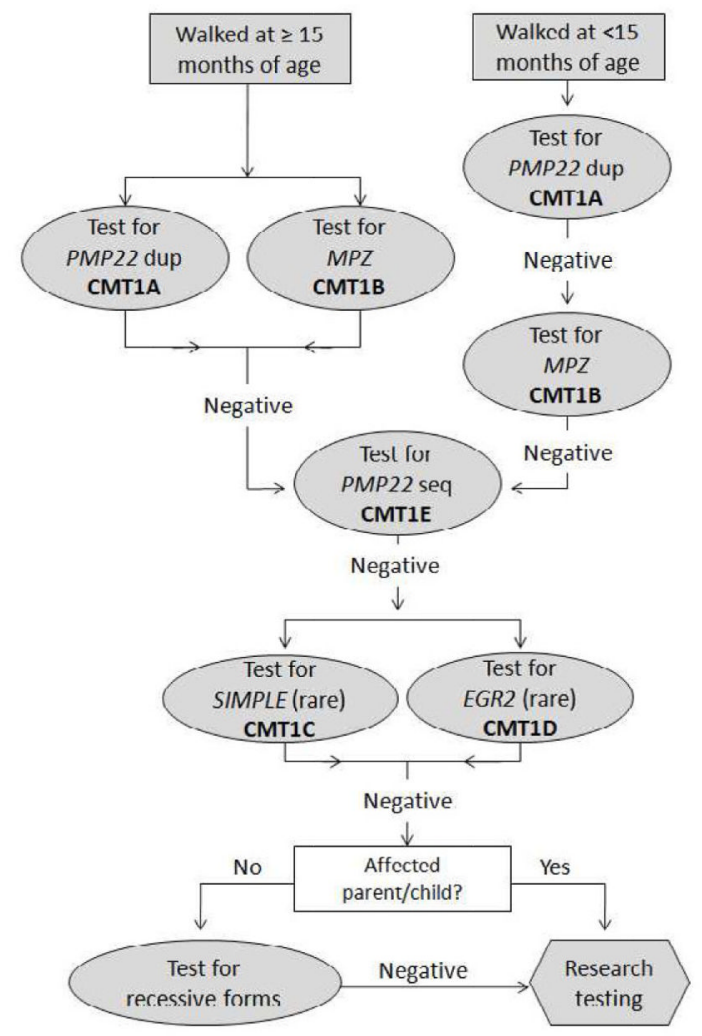

Figure 2.

Algorithm for the genetic diagnosis of patients with Charcot-Marie-Tooth disease and slow (A) or very slow (B) upper extremity motor nerve conduction velocities.

$\mathrm{MNCV}=$ motor nerve conduction velocity; $P M P 22=$ peripheral myelin protein 22; dup = duplication; $\mathrm{CMT}=$ Charcot-Marie-Tooth disease; $G J B 1=$ gap junction protein beta 1; Cx32 = Connexin 32; $M P Z=$ myelin protein zero; $L I T A F=$ lipopolysaccharide-induced $\mathrm{TNF}$ factor; seq = sequencing; $E G R 2=$ early growth response 2

From Saporta AS, Sottile SL, Miller LJ, et al. Charcot-Marie-Tooth disease subtypes and genetic testing strategies. Ann Neurol 2011; 69(1): 22 - 33; with permission 

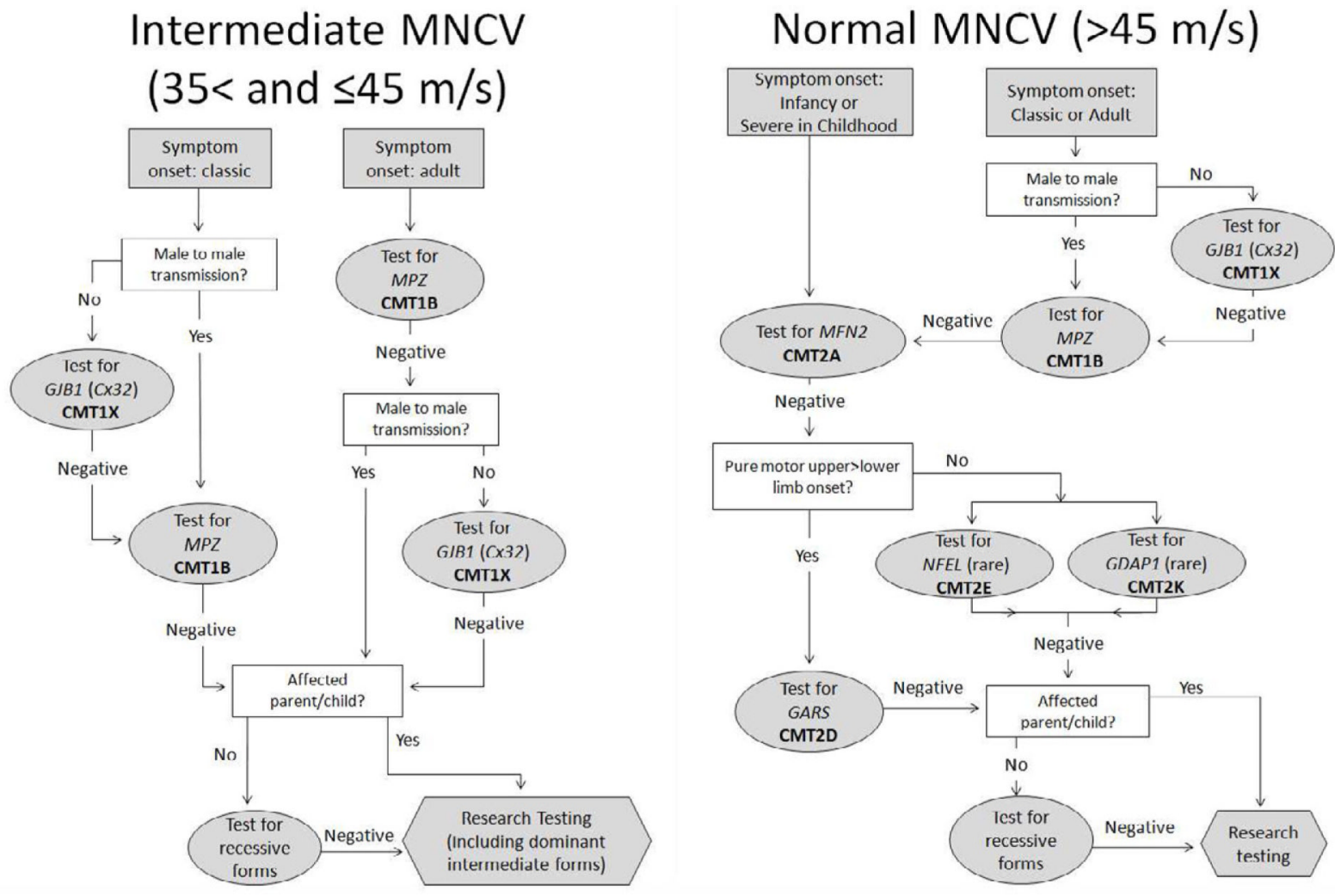

Figure 3.

Algorithm for the genetic diagnosis of patients with Charcot-Marie-Tooth disease and intermediate (A) or normal (B) upper extremity motor nerve conduction velocities.

$\mathrm{MNCV}=$ motor nerve conduction velocity; $\mathrm{CMT}=$ Charcot-Marie-Tooth disease; $G J B 1=$ gap junction protein beta $1 ; \mathrm{Cx} 32=$ Connexin $32 ; M P Z=$ myelin protein zero; $M F N 2=$ mitofusin 2; $N E F L=$ neurofilaments light polypeptide; $G D A P 1=$ ganglioside-induced differentiation-associated protein 1; GARS = glycyl-tRNA synthetase.

From Saporta AS, Sottile SL, Miller LJ, et al. Charcot-Marie-Tooth disease subtypes and genetic testing strategies. Ann Neurol 2011; 69(1): 22 - 33; with permission. 
Table 1

\section{Classification of Charcot-Marie-Tooth Disease}

\begin{tabular}{|c|c|c|}
\hline Type & Gene/Locus & Specific Phenotype \\
\hline \multicolumn{3}{|c|}{ Autosomal dominant (AD) CMT1 } \\
\hline \multirow[t]{2}{*}{ CMT1A } & Dup 17p (PMP22) & Classic CMT1 \\
\hline & $\begin{array}{l}\text { PMP22 (point } \\
\text { mutation) }\end{array}$ & Classic CMT1/DSS/CHN/HNPPs \\
\hline CMT1B & MPZ & CMT1/DSS/CHN/intermediate/CMT2 \\
\hline CMT1C & LITAF & Classic CMT1 \\
\hline CMT1D & EGR2 & Classic CMT1/DSS/CHN \\
\hline CMT1E & NEFL & $\begin{array}{l}\text { CMT2 but can have slow MNCVs in } \\
\text { CMT1 range +/- early-onset severe } \\
\text { disease }\end{array}$ \\
\hline \multicolumn{3}{|l|}{ HNPP } \\
\hline \multirow[t]{2}{*}{ HNPP } & Del 17p (PMP22) & Typical HNPP \\
\hline & $\begin{array}{l}\text { PMP22 (point } \\
\text { mutation) }\end{array}$ & Typical HNPP \\
\hline \multicolumn{3}{|l|}{$\begin{array}{l}\text { X-linked CMT1 } \\
\text { (CMT1X) }\end{array}$} \\
\hline CMT1X & GJB1 & $\begin{array}{l}\text { Intermediate }+/- \text { patchy MNCVs/male } \\
\text { MNCVs less than female MNCVs }\end{array}$ \\
\hline \multicolumn{3}{|c|}{ Autosomal recessive (AR) demyelinating CMT (CMT4) } \\
\hline CMT4A & GDAP1 & $\begin{array}{l}\text { Demyelinating or axonal, usually early } \\
\text { onset and severe/vocal cord and } \\
\text { diaphragm paralysis described/rare AD } \\
\text { CMT2 families described }\end{array}$ \\
\hline CMT4B1 & MTMR2 & $\begin{array}{l}\text { Severe CMT1/facial/bulbar/focally } \\
\text { folded myelin }\end{array}$ \\
\hline CMT4B2 & SBF2 & $\begin{array}{l}\text { Severe CMT } 1 / \text { glaucoma/focally folded } \\
\text { myelin }\end{array}$ \\
\hline CMT4C & SH3TC2 & $\begin{array}{l}\text { Severe CMT1/scoliosis/cytoplasmic } \\
\text { expansions }\end{array}$ \\
\hline CMT4D (HMSNL) & NDRG1 & $\begin{array}{l}\text { Severe CMT1/gypsy/deafness/tongue } \\
\text { atrophy }\end{array}$ \\
\hline CMT4E & EGR2 & Classic CMT1/DSS/CHN \\
\hline CMT4F & PRX & $\begin{array}{l}\text { CMT1/more sensory/focally folded } \\
\text { myelin }\end{array}$ \\
\hline CMT4H & FGD4 & CMT1 \\
\hline CMT4J & FIG4 & CMT1 \\
\hline CCFDN & CTDP1 & $\begin{array}{l}\text { CMT1/gypsy/cataracts/dysmorphic } \\
\text { features }\end{array}$ \\
\hline HMSN-Russe & $10 q 22-q 23$ & CMT1 \\
\hline CMT1 & $\begin{array}{l}\text { PMP22 (point } \\
\text { mutation) }\end{array}$ & Classic CMT1/DSS/CHN/HNPPs \\
\hline CMT1 & MPZ & CMT1/DSS/CHN/intermediate/CMT2 \\
\hline \multicolumn{3}{|c|}{ Autosomal dominant (AD) CMT 2} \\
\hline CMT2A & MFN2 & CMT2/usually severe/optic atrophy \\
\hline СMT2B & RAB7A & $\begin{array}{l}\text { CMT2 with predominant sensory } \\
\text { involvement and sensory complications }\end{array}$ \\
\hline CMT2C & $12 \mathrm{q} 23-\mathrm{q} 24$ & CMT2 with vocal cord and respiratory \\
\hline
\end{tabular}




\begin{tabular}{|c|c|c|}
\hline Type & Gene/Locus & Specific Phenotype \\
\hline & & involvement \\
\hline CMT2D & GARS & $\begin{array}{l}\text { CMT2 with predominant hand } \\
\text { wasting/weakness or dHMN V }\end{array}$ \\
\hline CMT2E & NEFL & $\begin{array}{l}\text { CMT2 but can have slow MNCVs in } \\
\text { CMT1 range }+/- \text { early-onset severe } \\
\text { disease }\end{array}$ \\
\hline CMT2F & HSPB1 (HSP27) & Classic CMT2 or dHMN II \\
\hline CMT2G & $12 \mathrm{q} 12-\mathrm{q} 13.3$ & Classic CMT2 \\
\hline CMT2L & HSPB8 (HSP22) & Classic CMT2 or dHMN II \\
\hline CMT2 & MPZ & CMT1/DSS/CHN/intermediate/CMT2 \\
\hline CMT2 (HMSNP) & $3 q 13.1$ & CMT2 with proximal involvement \\
\hline \multicolumn{3}{|c|}{ Autosomal recessive (AR) CMT2 (also called CMT4) } \\
\hline AR CMT2A & LMNA & $\begin{array}{l}\text { CMT2 proximal involvement and rapid } \\
\text { progression described/also causes } \\
\text { muscular } \\
\text { dystrophy/cardiomyopathy/lipodystrophy }\end{array}$ \\
\hline AR CMT2B & $19 \mathrm{q} 13.1-13.3$ & Typical CMT2 \\
\hline AR CMT2 & GDAP1 & $\begin{array}{l}\text { CMT1 or CMT2 usually early onset and } \\
\text { severe/vocal cord and diaphragm } \\
\text { paralysis described/rare AD CMT2 } \\
\text { families described }\end{array}$ \\
\hline \multicolumn{3}{|c|}{ Dominant intermediate CMT (DI-CMT) } \\
\hline DI-CMTA & $10 \mathrm{q} 24.1-25.1$ & Typical CMT \\
\hline DI-CMTB & DNM2 & Typical CMT \\
\hline DI-CMTC & YARS & Typical CMT \\
\hline \multicolumn{3}{|c|}{ Hereditary neuralgic amyotrophy (HNA) } \\
\hline HNA & SEPT9 & Recurrent neuralgic amyotrophy \\
\hline
\end{tabular}

AD, autosomal dominant; AR, autosomal recessive; CHN, congenital hypomyelinating neuropathy; CMT, Charcot-Marie-Tooth; CTDP1, CTD phosphatise subunit 1; Del, deletion; DMN2, dynamin 2; DSN, Dejerine Sottas neuropathy; Dup, duplication; EGR2, early growth response 2; FGD4, FYVE, RhoGEF and PH domain containing 4; FIG4, FIG 4 homologue; GARS, glycyl tRNA synthetase; GDAP1, ganglioside induced differentiation associated protein 1; GJB1, gap junction protein beta1; HNPP, hereditary neuropathy with liability to pressure palsies; HSP22, heat shock $22 \mathrm{kDa}$ protein 8; HSP27, heat shock $27 \mathrm{kDa}$ protein 1; KIF1Bb, kinesin family member 1B-b; LITAF, lipopolysaccharide induced tumour necrosis factor; LMNA, lamin A/C; MCV, motor conduction velocity ; MFN2, mitofusin 2; MPZ, myelin protein zero; MTMR2, myotubularin related protein 2; MTMR13, myotubularin related protein 13; NDRG1, N-myc downstream regulated gene 1; NEFL, neurofilament, light polypeptide $68 \mathrm{kDa}$; PMP22, peripheral myelin protein 22; PRX, periaxin; RAB7, RAB7, member RAS oncogene family; SEPT9, septin 9; SH3TC2, SH3 domain and tetratricopeptide repeats 2; YARS, tyrosyl tRNA synthetase.

From Reilly MM, Shy ME. Diagnosis and new treatments in genetic neuropathies. J Neurol Neurosurg Psychiatry 2009;80(12):1304Y1314; with permission. 
TABLE 2

\section{Classification of the Hereditary Sensory and Autonomic Neuropathies}

\begin{tabular}{|l|l|l|l|}
\hline Type & Inheritance & Gene/Locus & Specific Phenotype \\
\hline HSAN I & AD & SPTLC1 & $\begin{array}{l}\text { Mainly sensory, sensory complications, motor } \\
\text { involvement variable, men may be more severely } \\
\text { affected }\end{array}$ \\
\hline CMT2B & AD & RAB7A & Sensorimotor, sensory complications, no pain \\
\hline HSAN IB & AD & 3p22-p24 & Sensory, cough, gastroesophageal reflux \\
\hline HSAN II & AR & WNK1 & $\begin{array}{l}\text { Severe sensory complications, mutilations, onset } \\
\text { first 2 decades }\end{array}$ \\
\hline HSAN III & AR & IKBKAP & $\begin{array}{l}\text { Familial dysautonomia or Riley-Day syndrome, } \\
\text { prominent autonomic, absence fungiform papillae } \\
\text { of the tongue }\end{array}$ \\
\hline HSAN IV & AR & NTRK1 & $\begin{array}{l}\text { Congenital insensitivity to pain with anhidrosis, } \\
\text { severe sensory, anhidrosis, mental retardation, } \\
\text { unmyelinated fibers mainly affected }\end{array}$ \\
\hline HSAN V & AR & NTRK1 & $\begin{array}{l}\text { Congenital insensitivity to pain with mild } \\
\text { anhidrosis, no mental retardation, small } \\
\text { myelinated fibers mainly affected }\end{array}$ \\
\hline HSAN V & AR & NGF & $\begin{array}{l}\text { Congenital insensitivity to pain, minimal } \\
\text { autonomic, no mental retardation, mainly } \\
\text { unmyelinated fibers affected }\end{array}$ \\
\hline $\begin{array}{l}\text { Channelopathy- } \\
\text { associated } \\
\text { insensitivity to pain }\end{array}$ & AR & SCN9A & \begin{tabular}{l} 
Congenital insensitivity to pain, \\
\hline
\end{tabular} \\
\hline
\end{tabular}

AD, autosomal dominant; AR, autosomal recessive; CMT, Charcot-Marie-Tooth; HSN2, hereditary sensory neuropathy type II gene; IKBKAP, Inhibitor of kappa light polypeptide gene enhancer in B-cells, kinase complex-associated protein; NGFB, nerve growth factor beta polypeptide; NTRK1, neurotrophic tyrosine kinase receptor type 1; SCN9A, sodium channel, voltage gated, type IX, alpha subunit; RAB7, RAB7, member RAS oncogene family; SPLTC1, serine palmitoyltransferase, long chain base subunit-1.

From Reilly MM, Shy ME. Diagnosis and new treatments in genetic neuropathies. J Neurol Neurosurg Psychiatry 2009;80(12):1304Y1314.

Copyright 2009, with permission from BMJ Publishing Group Ltd; with permission. 
TABLE 3

\section{Classification of the Distal Hereditary Motor Neuropathies}

\begin{tabular}{llll}
\hline Type & Inheritance & Gene/Locus & Specific Phenotype \\
\hline dHMN I & AD & Unknown & Juvenile-onset dHMN \\
dHMN II & AD & $\begin{array}{l}\text { HSPB1 } \\
\text { (HSP27) }\end{array}$ & Adult-onset typical dHMN/CMT2F \\
dHMN II & AD & $\begin{array}{l}\text { HSPB8 } \\
\text { (HSP22) }\end{array}$ & Adult-onset typical dHMN/CMT2L \\
dHMN III & AR & $11 \mathrm{q} 13$ & Early onset, slowly progressive \\
dHMN IV & AR & $11 \mathrm{q} 13$ & Juvenile onset, diaphragmatic involvement \\
dHMN V & AD & GARS & Upper limb onset, slowly progressive/CMT2D \\
dHMN V & AD & BSCL2 & Upper limb onset, +/- spasticity lower limbs/Silver- \\
& & & Russell syndrome \\
dHMN VI & AR & IGHMBP2 & Spinal muscle atrophy with respiratory distress, \\
& infantile-onset respiratory distress \\
dHMN VIIA & AD & 2q14 & Adult onset, vocal cord paralysis \\
dHMN VIIB & AD & DCTN1 & Adult onset/vocal cord paralysis/facial weakness \\
dHMN/ALS4 & AD & SETX & Early onset, pyramidal signs \\
dHMN J & AR & $9 \mathrm{p} 21.1-p 12$ & Juvenile onset, pyramidal features, Jerash \\
congenital distal SMA & AD & $12 q 23-12 q 24$ & Antenatal onset, arthrogryposis \\
\hline
\end{tabular}

$\mathrm{AD}$, autosomal dominant; AR, autosomal recessive; BSCL2, Berardinelli-Seip congenital lipodystrophy 2 (Seipin); CMT, Charcot-Marie-Tooth; dHMN, distal hereditary motor neuropathy; DCTN1, dynactin1; HSP22, heat shock 22 kDa protein 8; HSP27, heat shock 27 kDa protein 1; GARS, glycyl tRNA synthetase; IGHMBP2, immunoglobulin mu binding protein 2; SETX, sentaxin; SMA: Spinal muscular atrophy.

From Reilly MM, Shy ME. Diagnosis and new treatments in genetic neuropathies. J Neurol Neurosurg Psychiatry 2009;80(12):1304-1314; with permission. 